\title{
PENINGKATAN PRODUKTIVITAS UKM HANDICRAFT DENGAN ALAT PLONG KERTAS BERTENAGA DONGKRAK Studi Kasus: UKM Gift Box di Kota Malang
}

\author{
Hery Budiyanto'), Erna Winansih' ${ }^{2)}$, Herril Brimantyo ${ }^{3)}$, Muhammad Iqbal ${ }^{4)}$ \\ ${ }^{1,2,4)}$ Fakultas Teknik Universitas Merdeka Malang \\ ${ }^{3)}$ Fakultas Ilmu Sosial \& Ilmu Politik Universitas Merdeka Malang \\ E-mail: hery.budiyanto@unmer.ac.id ${ }^{1)}$
}

\begin{abstract}
Abstrak
Persaingan ekonomi global menjadi tantangan untuk UKM produk kreatif bidang kerajinan. Permasalahan yang sering dihadapi adalah kapasitas produksi yang minim bila dibandingkan dengan permintaan konsumen terutama terkait dengan peralatan produksi dan desain produk. Masalah lain adalah media pemasaran yang kurang akan mempengaruhi minat konsumen untuk mendapatkan produk UKM produk kreatif bidang kerajinan. Untuk itu perlu adanya pengembangan produk kreatif UKM yang mempunyai nilai ekonomi dan daya saing tinggi serta mampu menyerap tenaga kerja sehingga dapat menekan angka pengangguran dan kemiskinan. Usaha skala Kecil dan Menengah punya potensi untuk dikembangkan dengan memanfaatkan semua sumber daya yang dimiliki baik sumber daya alam, sumber daya manusia dan budaya lokal, sehingga menjadi kekuatan ekonomi masyarakat setempat. Salah satu UKM Industri kreatif bidang kerajinan yang berkembang di Kota Malang adalah UKM yang memproduksi Gift Box yang dipilih sebagai mitra dalam Program Kemitraan Masyarakat (PKM) dengan fokus pembinaan pada aspek produksi, desain dan pemasaran. Pendampingan mitra UKM pada aspek telah meningkatkan produktivitas melalui pembuatan alat plong karton/kertas dengan tenaga dongkrak yang meningkatkan produksi hingga 2 kali lipat dibanding proses pemotongan manual.
\end{abstract}

Kata kunci: UKM, gift box, produktivitas

\section{PENDAHULUAN}

Indonesia telah mengalami krisis ekonomi yang menyebabkan jatuhnya perekonomian nasional. Banyak usaha-usaha skala besar pada berbagai sektor termasuk industri, perdagangan, dan jasa yang mengalami stagnasi bahkan sampai terhenti aktifitasnya pada tahun 1998. Namun, Usaha Mikro, Kecil, dan Menengah (UMKM) dapat bertahan dan menjadi pemulih perekonomian di tengah keterpurukan akibat krisis moneter pada berbagai sektor ekonomi. Kegiatan Usaha Mikro, Kecil, dan Menengah (UMKM) merupakan salah satu bidang usaha yang dapat berkembang dan konsisten dalam perekonomian nasional. UMKM menjadi wadah yang baik bagi penciptaan lapangan pekerjaan yang produktif. UMKM merupakan usaha yang bersifat padat karya, tidak membutuhkan persyaratan tertentu seperti tingkat pendidikan, keahlian (keterampilan) pekerja, dan penggunaan modal usaha relatif sedikit serta teknologi yang digunakan cenderung sederhana. UMKM masih memegang peranan penting dalam perbaikan perekonomian Indonesia, baik ditinjau dari segi jumlah usaha, segi penciptaan lapangan kerja, maupun dari segi pertumbuhan ekonomi nasional yang diukur dengan produk domestik bruto.
Usaha kecil dan menengah (UKM) merupakan salah satu bagian penting dari perekonomian suatu negara ataupun daerah. Berbagai upaya pengembangan UKM telah dilakukan, salah satunya dengan membangkitkan dan memperbanyak orang atau pengusaha baru di bidang UKM, sehingga masyarakat desapun diberi keterampilan dengan harapan keterampilan tersebut menjadi sebuah usaha kreatif yang memberi manfaat bagi perekonomian keluarga dan masyarakat desa. Selain itu, usaha kreatif tersebut juga dapat membukan kesempatan dan lapangan kerja baru bagi masyarakat (Hery, 2017).

Dalam menghadapi persaingan yang semakin ketat, UKM produk kreatif harus siap bersaing dalam ekonomi global (Sasono, Eko \& Rahmi, 2014). Untuk itu perlu adanya pengembangan produk kreatif UKM yang mempunyai nilai ekonomi dan daya saing tinggi serta mampu menyerap tenaga kerja sehingga dapat menekan angka pengangguran dan kemiskinan. Usaha skala Kecil dan Menengah punya potensi untuk dikembangkan dengan memanfaatkan semua sumber daya yang dimiliki baik sumber daya alam, sumber daya manusia dan budaya lokal, sehingga menjadi kekuatan ekonomi masyarakat setempat (Kurniawati, Fitri \& Mukzam, Mochamad Djudi. 2017).Dalam pengembangan UKM yang 
bergerakdalambidangkemasan,

makadiperlukandesain untuk kemasan produk yang tampilanproduknya lebih variatif, menarik dan eye catching (Rofieq, at.al., 2017)

Agar memudahkan pencapaian keberhasilan Program Kemitraan Masyarakat, maka pelaksanaannya harus difokuskan kepada sasaran yang mempunyai dampak besar terhadap peningkatan kesejahteraan masyarakat. Salah satu UKM Industri kreatif bidang kerajinan yang berkembang di Kota Malang adalah UKM yang memproduksi Gift Box.
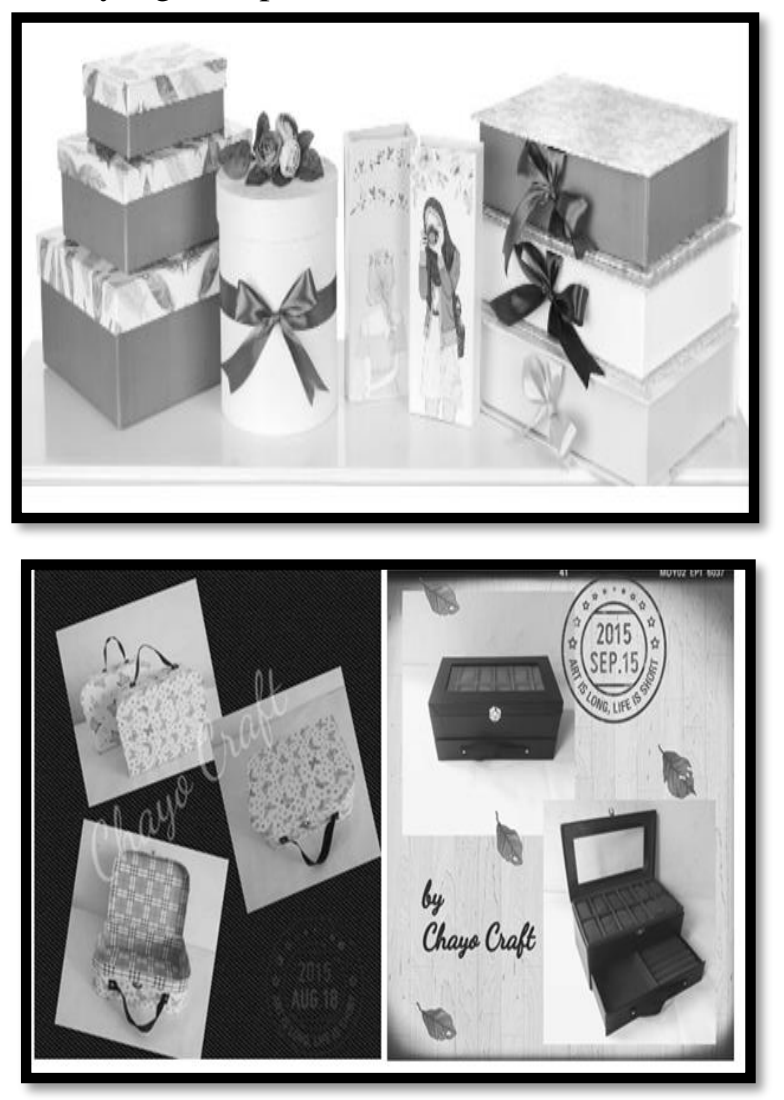

Gambar 1. Produk Gift Box

Bahan yang digunakan untuk membuat gift box cukup sederhana, diantaranya karton Jepang tebal, kertas kado, kertas hvs/samson, isolasi kertas, lem putih dan pita. Peralatan yang digunakan dalam memproduksi gift box juga sederhana, antara lain: gunting, cutter, penggaris berukuran besar dan lem tembak.

Pemasaran pengusaha gift box Kota Malang telah merata di Kota/Kabupaten di Provinsi Jawa Timur, bahkan telah mencapai berbagai kota di luar Jawa. Hal ini terjadi berkat pemasaran online melalui Instragram, Shopee dan Facebook yang selalu diupdate secara berkala. Cara pemasaran lain dilakukan melalui berbagai pameran Lokal Malang, Regional Jawa Timur maupun Nasional.

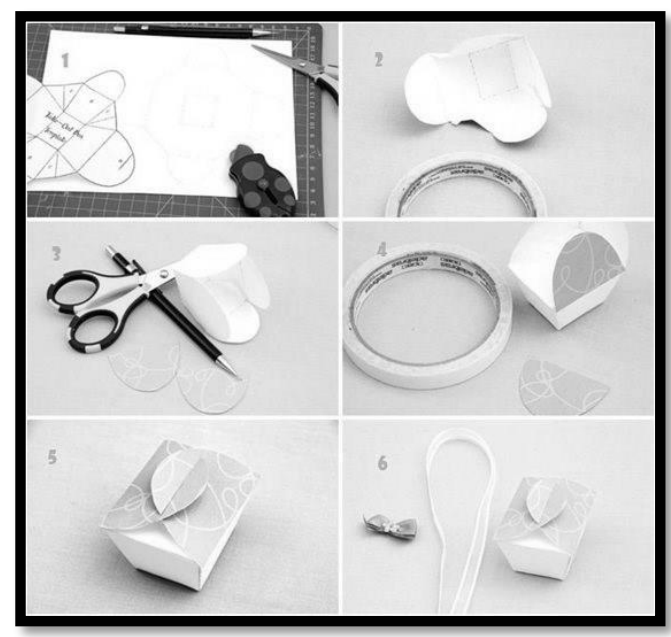

Gambar 2: Proses Pembuatan Gift Box

Permasalah yang masih dihadapi UKM Gift Box, antara lain:Permohonan produk gift box semakin meningkat sementara peralatan produksi masih dilakukan secara manual sehingga terjadi penumpukan order. Apabila persoalan ini dibiarkan akan menyebabkan daftar tunggu semakin panjang dan kemungkinan akan menurunkan tingkat kepercayaan pelanggan.

\section{METODE KEGIATAN}

\section{Produktivitas UKM}

Masalah yang banyak dialami oleh UKM adalah rendahnya produktivitas, terbatasnya akses modal, terbatasnya akses ke pasar, dan terbatasnya akses informasi mengenai sumberdaya dan teknologi, (Susilo, 2005). Disamping itu, kondisi UKM selalu dihadapkan pada kondisi yang tidak kontinyu, kurang sukses, susah berkembang atau bahkan menjadi mati. Oleh karena itu, Berkembangnya UKM masih menyimpan banyak permasalahan diantaranya terkait dengan pemasaran, produk, pengelolaan keuangan, permodalan, dan kualitas sumber daya manusia.

Program pengabdian ini merupakan penelitian tindakan (action research) yang menggunakan metode deskriptif kualitatif dengan studi kasus UKM yang bergerak dalam bidang Gift Box, terdapat 3 aspek yang menjadi fokus yaitu: produktivitas, desain produk, dan sarana penunjang pemasaran yang menjadi permasalahan usaha Gift Box.

Permasalahan dalam bidang produksi adalah proses pembuatan gift box yang hingga saat ini masih menggunakan peralatan sederhana berupa gunting, cutter, dan penggaris. Apabila pengusaha gift box mendapat order dalam jumlah besar akan mengalami kesulitan untuk memenuhi dalam waktu yang singkat. 
Langkah solusinya adalah pembuatan alat plong kertas dan karton sehingga kapasitas produksi dapat ditingkatkan.

\section{HASIL DAN PEMBAHASAN}

\section{Desain Alat Plong}

Alat plong dengan tenaga dongkrak ini dikembangkan berdasarkan diskusi antara UKM mengenai alat yang tepat guna, tidak memerlukan listrik dan mempunyai kemampuan potong yang tinggi, sehingga dibuat desain alatp long sebagaimana gambar berikut:

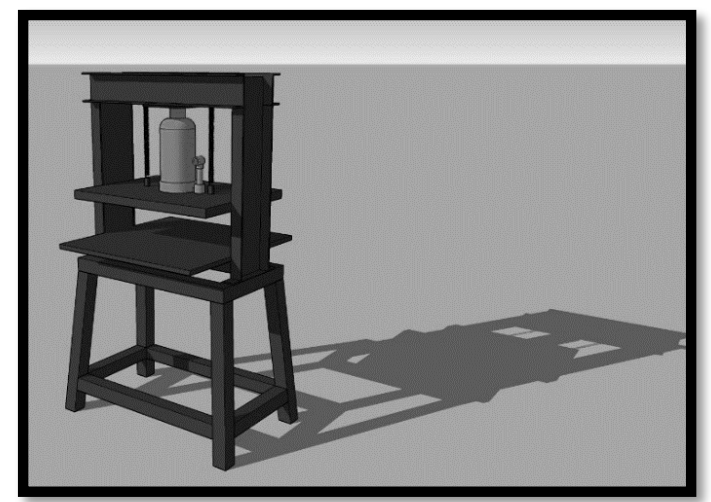

Gambar 3: DesainAlatPlongKertas Tenaga Dongkrak

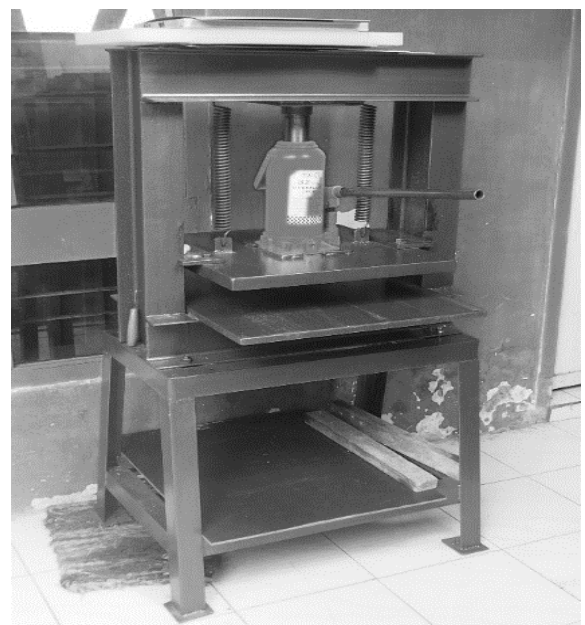

Gambar 4: Alat Plong Kertas Tenaga Dongkrak

Dalam mengatasi masalah kecepatan produksi dilakukan dengan pembuatan 1 buah alat plong kertas dan karton bertenaga dongkrak serta pembinaan operasional peralatan plong kertas selama 1 minggu. Dampaknya terlihat dari jumlah produk 100 buah gift box yang semula memerlukan waktu 7 hari dengan alat plong kertas/karton bertenaga dongkrak dapat diselesaikan dalam waktu 3 hari sehingga meningkatkan produktivitas lebih dari 2 (dua) kali dibandingkan produksi secara manual.

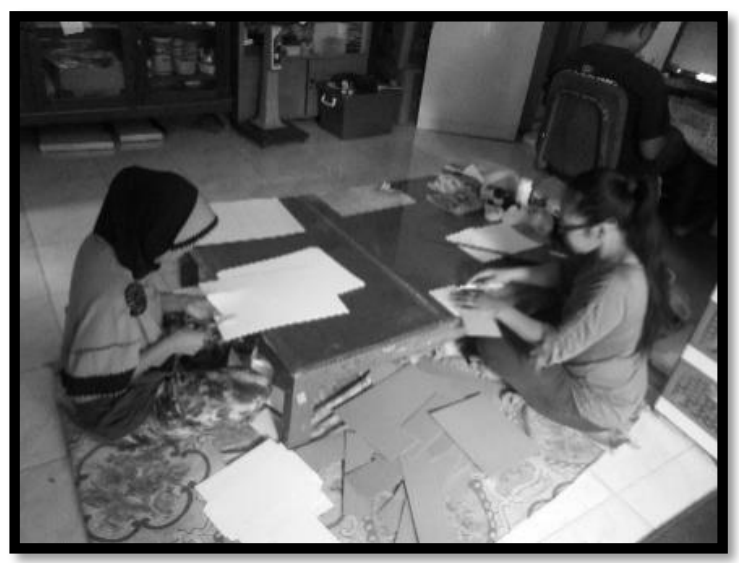

Gambar 5: Pemotongan Secara Manual

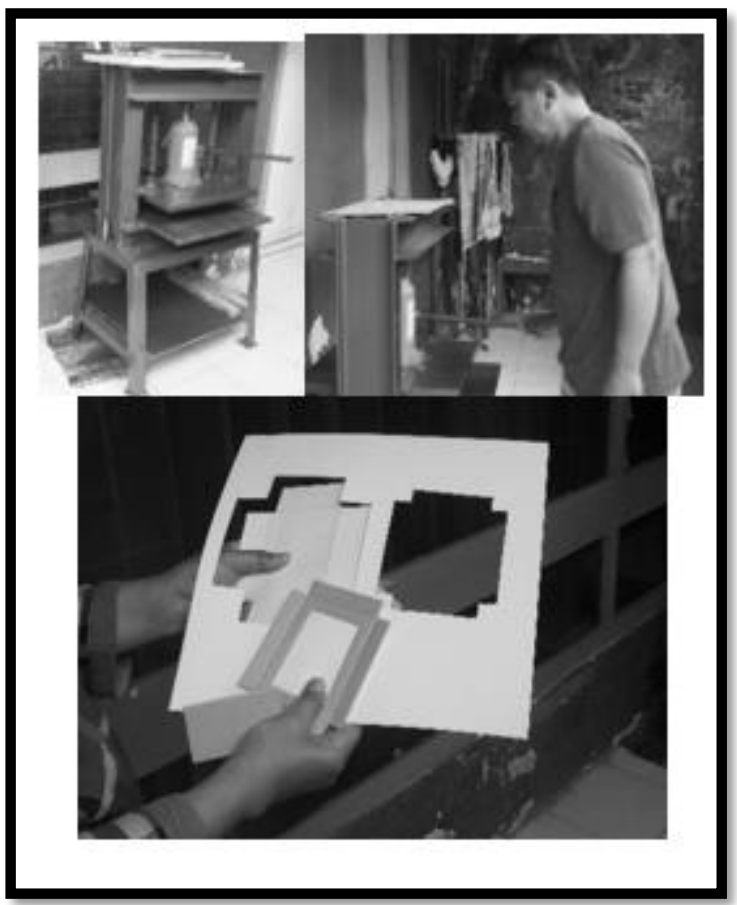

Gambar 6: PenggunaanPeralatan Plong Kertas/Karton Tenaga Dongkrak

\section{KESIMPULAN DAN SARAN}

\section{Kesimpulan}

Dalam menghadapi persaingan yang semakin ketat, UKM handicraft harus siap bersaing dalam ekonomi global. Untuk itu dilakukan pembinaan pengembangan produk kreatif UKM khususnya UKM bidang gift box sehingga mempunyai nilai ekonomi dan daya saing lebih tinggi, antara lain pada aspek produktivitas, desain dan pemasaran.

Pada aspek produksi, telah diberikan stimulan berupa alat plong kertas/karton bertenaga dongkrak yang meningkatkan 
produktivitas lebih dari 2 kali dibanding produksi secara manual, hal ini berdampak positif dalam jumlah produksi dan omset UKM Gift Box per bulannya. Pada aspek desain produk dapat dilihat dari peningkatan kemampuan desain UKM gift box dalam menggunakan aplikasi desain grafis Corel Draw yang telah menghasilkan 10 desain baru dan 10 desain pengembangan. Pada aspek pemasaran telah dilakukan redesain dan didicetak 1000 lembar brosur dengan desain baru serta redesain katalog sehingga dihasilkan 1 buah Katalog Produk baru.

\section{Saran}

Alat plong kertas/karton bertenaga dongkrak dapat dikembangkan untuk kebutuhan berbagai jenis kerajinan, misalnya: kain, sandal, dll.

Pengabdian dapat dilanjutkan dengan pembinaan dalam pengembangan sarana pameran untuk meningkatkan pasar kerajinan.

\section{REFERENSI}

Budiyanto, H., Rofieq, M. 2016. Menumbuhkembangkan WirausahaMahasiswadan Alumni Melalui Program Ipteks bagi Kewirausahaan di Universitas Merdeka Malang. Jurnal ABDIMAS Volume 1 Nomor 1 Desember 2016, LPPM Universitas Merdeka Malang

Kurniawati, Fitri \& Mukzam, Mochamad Djudi. 2017. "Pelaksanaan dan Dampak Program Kemitraan dan Bina Lingkungan PT Pelabuhan Indonesia III (Persero) (Studi Kasus pada Kampung Lawas Maspati Surabaya)". Jurnal Administrasi Bisnis (JAB)|Universitas Brawijaya, Vol. 50 No. 2 September 2017.

Rofieq, at.al. 2017. Pelatihan Desain Kemasan Produk Untuk UMKM Kerajinan, Kuliner dan Posdaya. JurnalAbdimasUnmer Malang. No.2,Vo.2., Desember 2017.

Sasono, Eko dan Rahmi Y. 2014. "Manajemen Inovasi pada Usaha Kecil Menengah”. Jurnal STIE Semarang, Vol 6, No 3, Edisi Oktober 2014 (ISSN : 2252 - 7826), Hal. 74-90 